\title{
FRACTURE TOUGHNESS OF CEMENTITIOUS
}

\section{MATERIALS BY SiGMA PROCEDURE}

\author{
Muzo C. MUNWAM ${ }^{1}$, Masayasu $\mathrm{OHTSU}^{2}$ and Mitsuhiro SHIGEISHI ${ }^{3}$ \\ ${ }^{1}$ Member of JSCE, Graduate School of Science and Technology, Kumamoto University \\ (Kurokami 2-39-1, Kumamoto 860-8555, Japan) \\ ${ }^{2}$ Member of JSCE, Dr. of Eng., Professor, Dept. of Civil Eng. \& Arch., Kumamoto University \\ ${ }^{3}$ Member of JSCE, Dr. of Eng., Associate Professor, Dept. of Civil Eng. \& Arch., Kumamoto \\ University
}

\begin{abstract}
A quantitative information on kinematics of cracking mechanisms can be obtained from the moment tensor analysis of acoustic emission (AE). According to the SiGMA (Simplified Green's functions for Moment tensor Analysis) procedure, crack orientation and crack types are determined. Based on the theory of linear elastic fracture mechanics (LEFM), crack extension under mixed mode fracture is determined by the maximum circumferential stress criterion. A relation between the direction of crack determined from the moment tensor components and the stress intensity factors is studied and applied to estimate the normalized stress intensity factors, $\mathrm{K}_{\mathrm{I}}{ }^{*}$ and $\mathrm{K}_{\mathrm{II}}{ }^{*}$ in cementitious materials.
\end{abstract}

Key Words: fracture toughness, Acoustic Emission (AE), SiGMA procedure, stress intensity factors

\section{INTRODUCTION}

In fracture mechanics, based on the principle of energy equilibrium in brittle materials, numerous researchers have studied basic theories in order to come into solution to the problematic mode of mechanical failure in concrete structures.

Under loading, concrete holds fracture toughness that causes the fracture process zone nucleated ahead of the notch. Research on the fracture process zone in concrete has been intensively studied ${ }^{1), 2)}$.

The fracture toughness is a material characteristic, which by means of a suitable fracture criterion is represented by the critical stress intensity factor, $\mathrm{K}_{\mathrm{IC}}$, in the linear elastic fracture mechanics (LEFM). In a numerical analysis of mixed-mode fracture of concrete $^{3)}$, the concept is successfully applied.

Acoustic Emission (AE) has been studied in different ways by several investigators. The terminology of source characterization was established, as the determination of crack kinetics by the deconvolution analysis ${ }^{4}$. The theory of $\mathrm{AE}$ wave motions was generalized on the basis of the elastodynamics and the dislocation theory ${ }^{5), 6}$. Earlier, the moment tensor analysis was attempted in glass due to indentation, by assuming the failure modes ${ }^{7)}$. A simplified and stable procedure known as SiGMA (Simplified Green's functions for Moment tensor Analysis) procedure ${ }^{8)}$ was developed to determine the moment tensor components in the general case Based on the eigenvalues and eigenvectors of the moment tensor components, crack types and crack direction are determined. In the present paper, the maximum circumferential stress criterion in LEFM and the crack direction determined by SiGMA procedure are applied to the estimation of the normalized stress intensity factors $\mathrm{K}_{\mathrm{I}}^{*}=\mathrm{K}_{\mathrm{I}} / \mathrm{K}_{\mathrm{IC}}$ and $\mathrm{K}_{\mathrm{II}}{ }^{*}=\mathrm{K}_{\mathrm{II}} / \mathrm{K}_{\mathrm{IC}}$.

\section{MOMENT TENSOR .AND SOURCE REPRESENTATION}

An internal defect (crack) in a solid can be mathematically represented as shown in Fig. 1. With vector $\boldsymbol{n}$, a unit vector normal to crack surface $F$ is prescribed. Due to micro-fracturing, displacement discontinuity $b(y, t)$ is defined as a dislocation vector or Burgers vector. The dynamic nature of vector $\boldsymbol{b}(\mathrm{y}, \mathrm{t})$ generates elastic waves, which are detected by an AE sensor as AE waves. In this case, crack kinematics in Fig. 1 are represented by an equivalent tensor in Eq.(1). The crack motion vector $\boldsymbol{b}(\mathrm{y}, \mathrm{t})$ at point $\mathbf{y}$ is set to be equal to $b(\mathrm{y}) l S(\mathrm{t})$, where $b(y)$ represents the magnitude of crack displacement, $l$ is the direction vector, $S(\mathrm{t})$ is the time function. $C_{\text {pqkl }}$ represent the elastic constants and $\Delta V$ is the crack volume. 


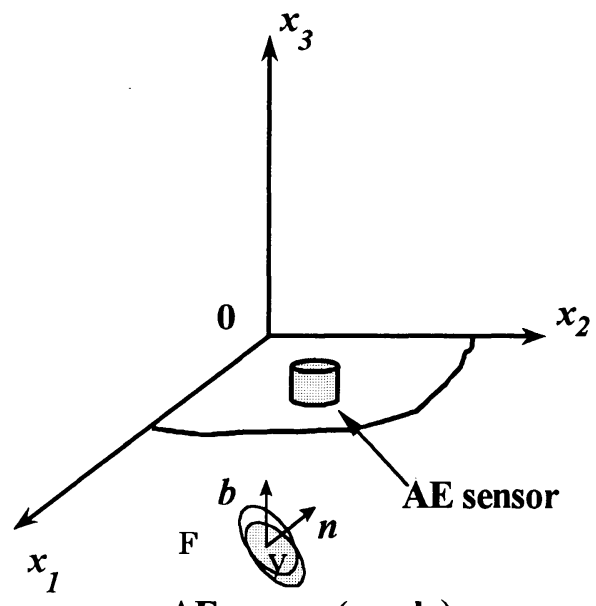

AE source (crack)

Fig. $1 \mathrm{AE}$ sensor and crack configuration

$$
\begin{aligned}
& \int_{F} C_{p q k l}\left[b(y) l_{k}\right] n_{l} d s=\left[C_{p q k l} l_{k} n_{l}\right]\left[\int_{F} b(y) d s\right] \\
& =\left[C_{p q k l} l_{k} n_{l}\right] \Delta V=m_{p q} .
\end{aligned}
$$

In an isotropic elastic material, moment tensor components can be represented,

$$
\begin{aligned}
& m_{11}=\lambda\left(l_{1} n_{1}+l_{2} n_{2}+l_{3} n_{3}\right)+2 \mu l_{1} n_{1} \\
& m_{12}=\mu\left(l_{1} n_{2}+l_{2} n_{1}\right) \\
& m_{13}=\mu\left(l_{1} n_{3}+l_{3} n_{1}\right) \\
& m_{22}=\lambda\left(l_{1} n_{1}+l_{2} n_{2}+l_{3} n_{3}\right)+2 \mu l_{2} n_{2} \\
& m_{23}=\mu\left(l_{2} n_{3}+l_{3} n_{2}\right) \\
& m_{33}=\lambda\left(l_{1} n_{1}+l_{2} n_{2}+l_{3} n_{3}\right)+2 \mu l_{3} n_{3}
\end{aligned}
$$

Here, $\mu$ and $\lambda$ are Lame constants. These tensor components are illustrated in Fig. 2.

In the SiGMA procedure, eigenvalues are decomposed of the shear ratio component $\mathbf{X}$, the tensile deviatoric component $\mathbf{Y}$, and the tensile hydrostatic mean component $\mathbf{Z}$. The pure shear crack corresponds to the case that $\mathbf{X}=100 \%$ and $\mathbf{Y}$ $=\mathbf{Z}=0 \%$, while the pure tensile is identical to the case $\mathbf{X}=0 \%$. Thus the shear ratio $\mathbf{X}$ dictates the contribution of shear motion at the crack surface.

\section{MIXED-MODE FRACTURE STRESS INTENSITY FACTORS}

AND

Erdogan and $\mathrm{Sih}^{9)}$ proposed the maximum circumferential stress criterion in the mixed-mode fracture. Fracture initiation is governed by the maximum circumferential stress in Eq.(3).

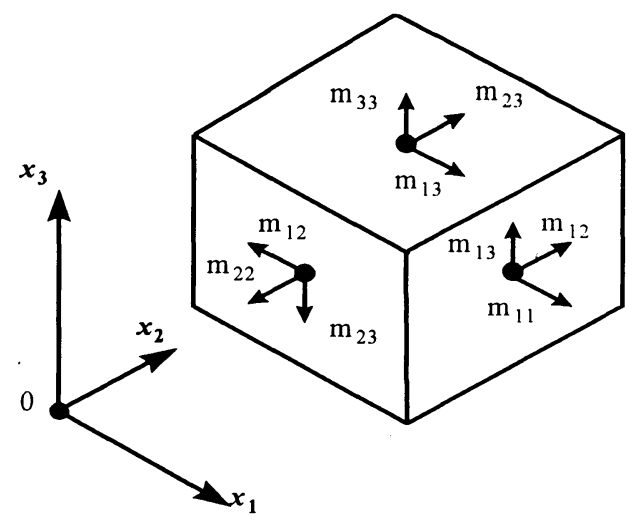

Fig. 2 Moment tensor components

As given in Fig. 3, the direction $\theta$ of crack extension from a pre-existing crack can be determined from Eq.(4),

$\cos \theta / 2\left[\mathrm{~K}_{\mathrm{I}} \cos ^{2} \theta / 2-3 / 2 \mathrm{~K}_{\mathrm{I}} \sin \theta\right]=\mathrm{K}_{\mathrm{IC}}$

$\mathrm{K}_{\mathrm{I}} \sin \theta+\mathrm{K}_{\mathrm{II}}(3 \cos \theta-1)=0$

where $\mathrm{K}_{\mathrm{I}}$ and $\mathrm{K}_{\mathrm{II}}$ are the stress intensity factor of mode I and mode II, respectively. $\mathrm{K}_{\mathrm{IC}}$ is the critical stress intensity factor of mode I

The normalized stress intensity factors, $\mathrm{K}_{\mathrm{I}}^{*}$ and $\mathrm{K}_{\mathrm{II}}{ }^{*}$ are computed from Eqs.(3) and (4) as,

$\mathrm{K}_{\mathrm{I}}{ }^{*}=\mathrm{K}_{\mathrm{I}} / \mathrm{K}_{\mathrm{IC}}=(3 \cos \theta-1) /[\cos \theta / 2(\cos \theta+1)]$

$\mathrm{K}_{\mathrm{II}}{ }^{*}=\mathrm{K}_{\mathrm{II}} / \mathrm{K}_{\mathrm{IC}}=-\sin \theta /[\cos \theta / 2(\cos \theta+1)]$

A key factor to compute the normalized stress intensity factors is the direction $\theta$ of crack extension. The direction $\theta$ can be determined from vectors $n^{0}$ and $n^{1}$ as shown in Fig. 3 and is equal to $\cos ^{-1}\left(n^{0} \cdot n^{1}\right)$. The orientation $\boldsymbol{l}$ and $\boldsymbol{n}$ are theoretically obtained from the eigenvectors of the moment tensor components. In the SiGMA procedure, unit vectors $\mathrm{e}_{1}, \mathrm{e}_{2}, \mathrm{e}_{3}$ of direction $l+n, l \times n$ and $l-n$, are recovered, where $\mathbf{x}$ means the vector product. Thus the two vectors are determined as,

$$
\begin{aligned}
& l=\left(\left[2+2 l_{\mathrm{k}} n_{\mathrm{k}}\right]^{1 / 2} \mathrm{e}_{1}+\left[2-2 l_{\mathrm{k}} n_{\mathrm{k}}\right]^{1 / 2} \mathrm{e}_{3}\right) / 2 \\
& \boldsymbol{n}=\left(\left[2+2 l_{\mathrm{k}} n_{\mathrm{k}}\right]^{1 / 2} \mathbf{e}_{\mathbf{1}}-\left[2-2 l_{\mathrm{k}} n_{\mathrm{k}}\right]^{1 / 2} \mathbf{e}_{3}\right) / 2
\end{aligned}
$$

To apply Eqs.(3) and (4), a coordinate transformation is required as the direction of vector $\mathbf{e}_{2}$ corresponds to the $x_{3}$-axis in a new coordinate system. The base vectors $e_{1}$ and $e_{3}$ are transformed into new vectors $\mathbf{e}_{1}{ }^{*}$ and $\mathbf{e}_{2}{ }^{*}$, respectively. Then, new vectors $\boldsymbol{l}^{*}$ and $\boldsymbol{n}^{*}$ in the new coordinate system are recovered as, 
Table 1 Mixture proportions

\begin{tabular}{|c|c|c|c|c|c|c|c|}
\hline & \multicolumn{4}{|c|}{$\begin{array}{l}\text { weight per volume } \\
\left(\mathrm{kg} / \mathrm{m}^{3}\right)\end{array}$} & \multirow{2}{*}{$\begin{array}{l}\text { admix } \\
\text { ture } \\
\text { (cc) }\end{array}$} & \multirow{2}{*}{$\begin{array}{l}\text { slump } \\
(\mathrm{cm})\end{array}$} & \multirow{2}{*}{$\begin{array}{l}\text { air } \\
(\%)\end{array}$} \\
\hline & W & C & $S$ & G & & & \\
\hline Concrete & 172 & 346 & 834 & 1021 & 104 & 8.0 & 5.0 \\
\hline Mortar & 342 & 570 & 1140 & & & & \\
\hline
\end{tabular}

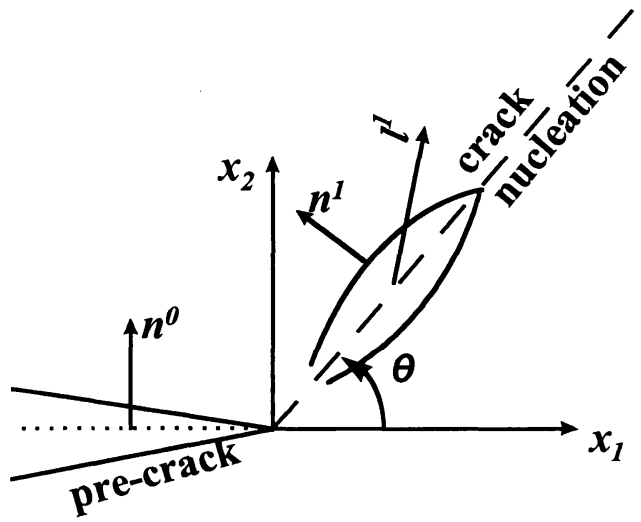

Fig. 3 Configuration of crack extension from pre-cracked

$$
\begin{aligned}
& l^{*}=\left(\left[2+2 l_{\mathrm{k}} n_{\mathrm{k}}\right]^{1 / 2} \mathrm{e}_{1}{ }^{*}+\left[2-2 l_{\mathrm{k}} n_{\mathrm{k}}\right]^{1 / 2} \mathrm{e}_{2}{ }^{*}\right) / 2 \\
& n^{*}=\left(\left[2+2 l_{\mathrm{k}} n_{\mathrm{k}}\right]^{1 / 2} \mathrm{e}_{1}{ }^{*}-\left[2-2 l_{\mathrm{k}} n_{\mathrm{k}}\right]^{1 / 2} \mathrm{e}_{2}{ }^{*}\right) / 2
\end{aligned}
$$

Due to crack extension from the pre-existing crack, it is derived that $\cos \theta=\boldsymbol{n}^{0} \cdot \boldsymbol{n}^{*}$. Then, the normalized stress intensity factors, $K_{\mathrm{I}}^{*}$ and $\mathrm{K}_{\mathrm{II}}{ }^{*}$ can be determined from Eqs.(5) and (6).

\section{EXPERIMENTS}

\section{(1) Specimens}

Beam specimens of concrete and mortar of dimensions $10 \mathrm{~cm} \times 10 \mathrm{~cm} \times 40 \mathrm{~cm}$ were made, and curing in water for 28 days in the standard room $\left(20^{\circ} \mathrm{C}\right)$. Mixture proportions and mechanical properties are summarized in Tables 1 and 2. These mechanical properties were obtained from cylindrical specimens of $10 \mathrm{~cm}$ in diameter and 20 $\mathrm{cm}$ in height.

\section{(2) Fracture test}

Three-point bending tests were carried out in type 1 (center notch) and type 2 (off-center notch) of concrete and mortar. A sawed pre-cracked notch of $30 \mathrm{~mm}$ depth and $1 \mathrm{~mm}$ width was introduced in all specimens. Experimental set-up is shown in Fig. 4.

As shown in the figure, six $\mathrm{AE}$ sensors were attached on the top, the bottom, the back and front
Table 2 Mechanical properties

\begin{tabular}{|l|c|c|c|c|c|}
\cline { 2 - 6 } \multicolumn{1}{c|}{} & $\begin{array}{l}\text { compres- } \\
\text { sive } \\
\text { strength } \\
(\mathrm{MPa})\end{array}$ & $\begin{array}{l}\text { tensile } \\
\text { strength } \\
(\mathrm{MPa})\end{array}$ & $\begin{array}{l}\text { Poisson's } \\
\text { ratio }\end{array}$ & $\begin{array}{l}\text { Young's } \\
\text { modulus } \\
(\mathrm{GPa})\end{array}$ & $\begin{array}{l}\text { P-wave } \\
\text { velocity } \\
(\mathrm{m} / \mathrm{s})\end{array}$ \\
\hline Concrete & 52.8 & 4.12 & 0.24 & 32.5 & 4730 \\
\hline Mortar & 53.7 & 2.93 & 0.19 & 23.4 & 4130 \\
\hline
\end{tabular}

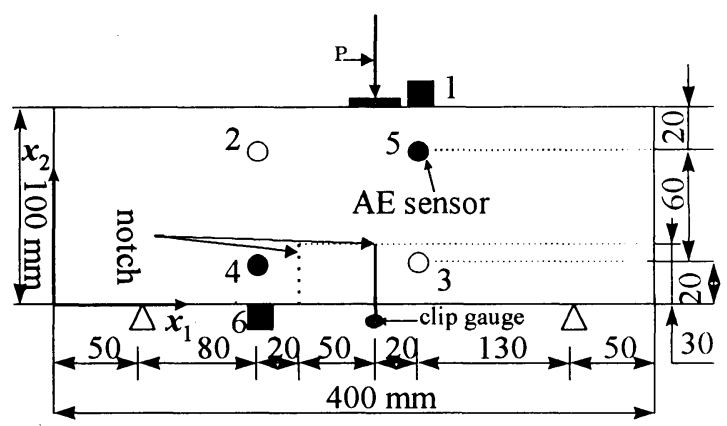

Fig.4 Experimental set-up and $\mathrm{AE}$ sensors location

of the specimen to cover a plausible fracture process zone. Location of notch and loading position for type 1 are indicated by solid lines and the notch position for type 2 is indicated by broken line. AE sensors employed were of the resonance frequency $150 \mathrm{kHz}$. For measuring system, the frequency range was $200 \mathrm{kHz}-1 \mathrm{MHz}$ and the amplification was $60 \mathrm{~dB}$ gain.

A servo-valve load-control machine was used. The loading speed of $0.01 \mathrm{~mm} / \mathrm{min}$ was applied to the type 1 specimens, whereas the loading speed applied to the type 2 was $0.02 \mathrm{~mm} / \mathrm{min}$. This is because crack extension of type 1 was faster than that of type 2 . Inserting a clip gauge into the notch the crack-mouth opening displacement (CMOD) was also measured.

\section{RESULTS AND DISCUSSION}

\section{(1) Crack locations and crack kinematics}

SiGMA procedure was applied to AE waveforms detected, and locations and moment tensor components were determined. Crack types and crack orientations were then analyzed. AE sources were classified into tensile cracks, shear cracks and mixed mode. AE sources with the shear ratio smaller than $40 \%$ were classified into tensile cracks, while these of shear ratios larger than $60 \%$ were classified as shear cracks. AE sources with the shear ratio between $40 \%$ and $60 \%$ were classified as mixed-mode. To select reliable solutions a procedure named post-SiGMA was performed ${ }^{1())}$. 
(a) Concrete specimen (type 1)

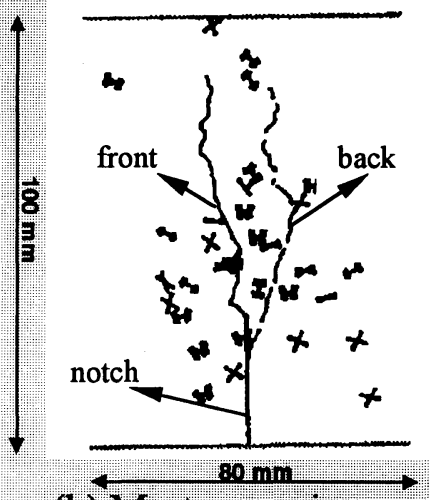

(b) Mortar specimen (type 1)

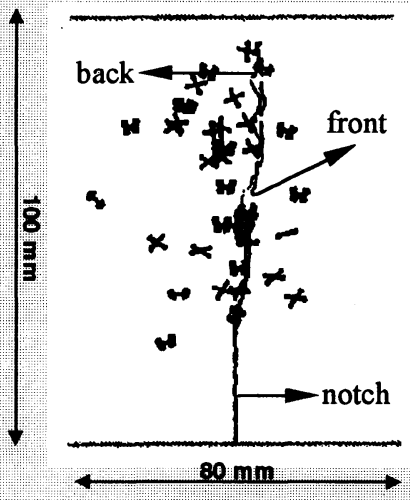

(c) Concrete specimen (type 2)

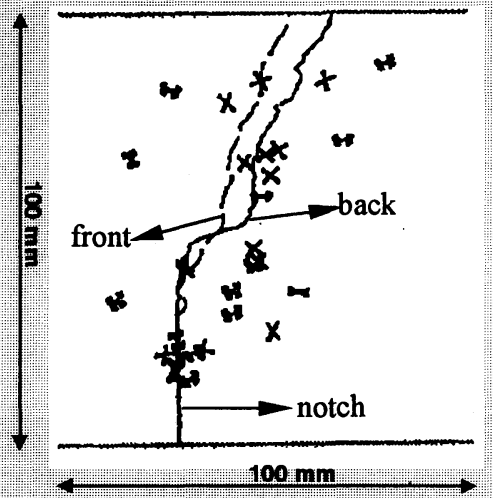

(d) Mortar specimen (type 2)

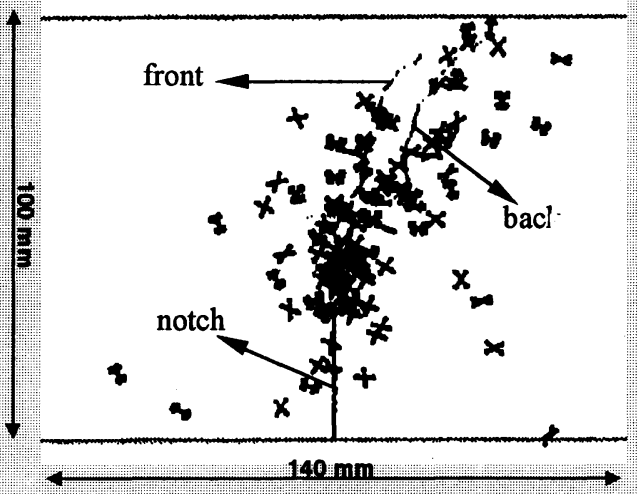

Fig 5 Results of cracks locations and cracks kinematics from SiGMA

Table 3 Number of AE hits

\begin{tabular}{|l|c|l|l|c|c|}
\cline { 3 - 6 } \multicolumn{2}{c|}{} & $\begin{array}{l}\text { total } \\
\text { AE } \\
\text { hits }\end{array}$ & $\begin{array}{l}\text { clear } \\
\text { records }\end{array}$ & $\begin{array}{l}\text { SiGMA- } \\
\text { analysis }\end{array}$ & $\begin{array}{l}\text { post- } \\
\text { analysis }\end{array}$ \\
\hline \multirow{3}{*}{ Concrete } & type 1 & 205 & 177 & 137 & 36 \\
\cline { 2 - 6 } & type 2 & 515 & 212 & 143 & 29 \\
\hline \multirow{3}{*}{ Mortar } & type 1 & 254 & 207 & 147 & 43 \\
\cline { 2 - 6 } & type 2 & 975 & 609 & 409 & 102 \\
\hline
\end{tabular}

Theoretical AE waveforms at AE sensor locations were synthesized, by substituting $\mathrm{AE}$ source location and the moment tensor components into the integral representation of $\mathrm{AE}$ waveform. Then SiGMA procedure was applied to the synthetic AE waveforms. AE sources, of which crack kinematics in the post-SiGMA analysis were in good agreement with those in the original SiGMA analysis, were selected as reliable solutions. The numbers of the $\mathrm{AE}$ hits detected in the tests are summarized in Table 3. AE hit is defined as one $\mathrm{AE}$ event for which $\mathrm{AE}$ waveforms are recorded at all channels.
In this table, the total $\mathrm{AE}$ hits collected after the test, those of clearly recorded, those after the SiGMA analysis and those selected as reliable solutions are shown.

Results after the post analysis are plotted in Fig. 5 Crack kinematics are given at their locations with directing two vectors $\boldsymbol{l}$ and $\boldsymbol{n}$, which are determined from Eq.(7). Tensile cracks are indicated by arrow symbol, while shear cracks and mixed-mode cases are indicated by cross symbol. As matter of course, the angles between the two vectors are considerably small in the case of tensile cracks. For the case of the type 1 of concrete, it is observed that crack extends tortuously from the notch. Corresponding to the fracture process zone (FPZ), a cluster of the AE sources, which contain tensile cracks, shear and mixed-mode cracks are observed. In the type 2 of concrete, crack propagation follows the maximum tensile stress direction. Tensile cracks are observed more in the broader region than shear and mixedmode cracks. In the case of the type 1 of mortar, AE sources were intensely observed ahead of the notch. In the case of the type 2 of mortar, AE sources are more actively observed than of concrete. 
(a) Concrete specimen (type 1)

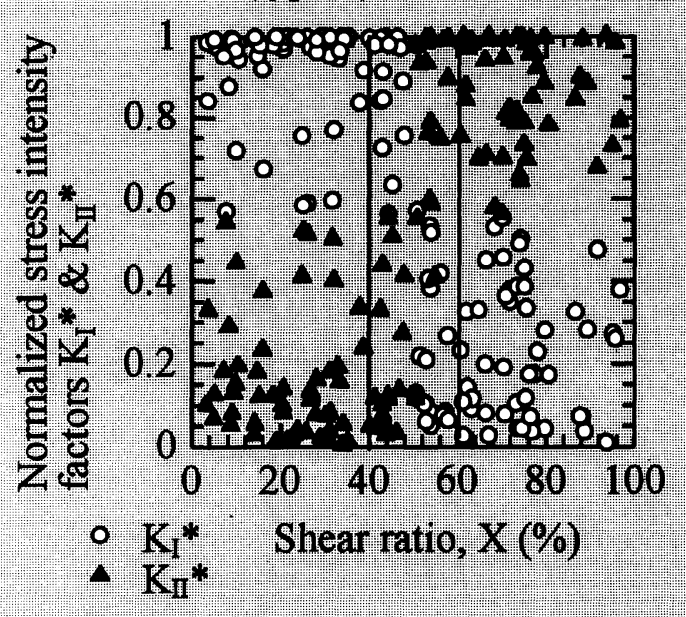

(b) Mortar specimen (type 1)

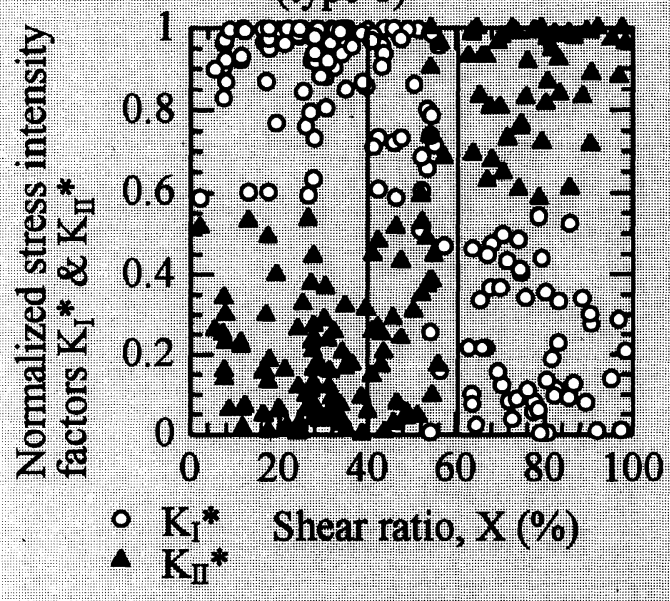

(c) Concrete specimen (type 2)

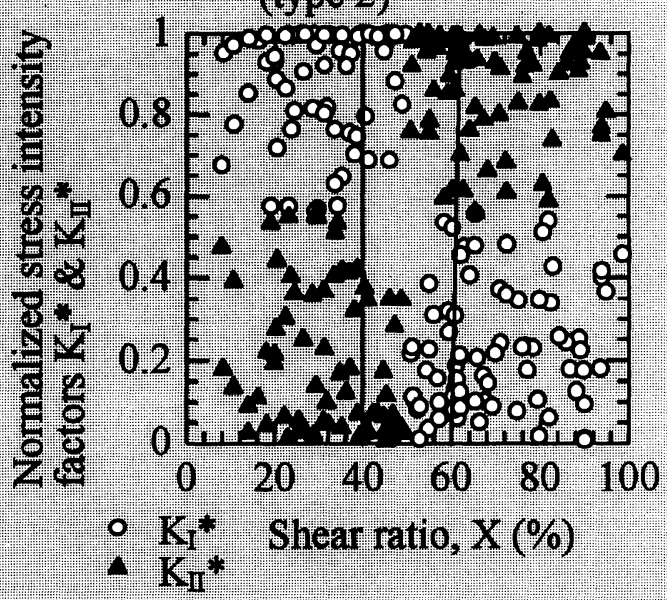

(d) Mortar specimen (type 2)

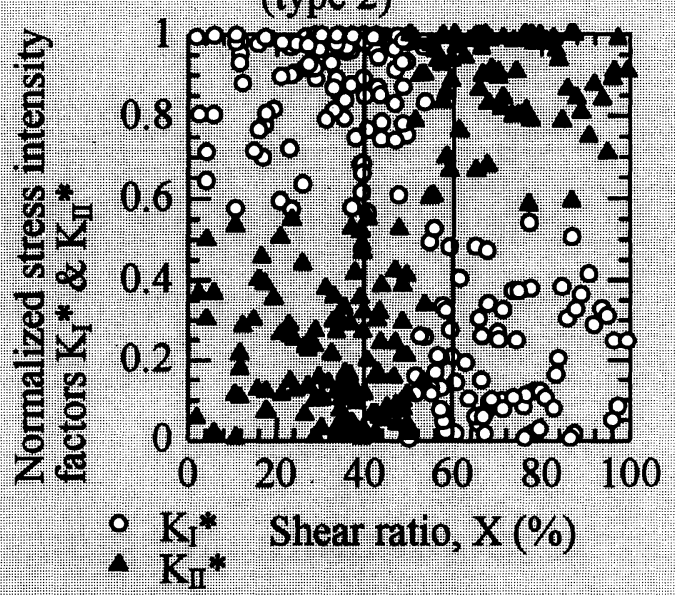

Fig 6 Relation between normalized stress intensity factors and shear ratios

From these results it is confirmed that the size of the fracture process zone (FPZ) is dependent on the size of aggregate ${ }^{11}$. The larger aggregate is mixed, the wider fracture process zone is nucleated.

\section{(2) Normalized stress intensity factors and shear ratio}

For each $\mathrm{AE}$ source, the direction of crack normal $n^{*}$ was obtained from Eq.(8) after determining the moment tensor components, and then $\cos \theta$ was obtained. The normalized stress intensity factors are estimated from Eqs.(5) and (6) and compared with the shear ratio. Results are plotted in Fig. 6. Here, the normalized stress intensity factors are estimated by only the absolute values. AE sources of which the shear ratio $X$ is less than $40 \%$ have definitely the larger $K_{I}^{*}$ values, while $K_{I I}^{*}$ is dominant in $A E$ sources of which the shear ratio $X$ is larger than $60 \%$. From these results it is concluded that the criterion for crack-type classification in the SiGMA procedure is in reasonable agreement with the dominant mode of the stress intensity factors. These $\mathrm{AE}$ sources correspond to $\mathrm{AE}$ hits in the third column of Table 3. This means that not only the normalized stress intensity factors for the reliable solutions but also those for all AE sources after SiGMA analysis are analyzed. 
(a) Concrete specimen (type 1)

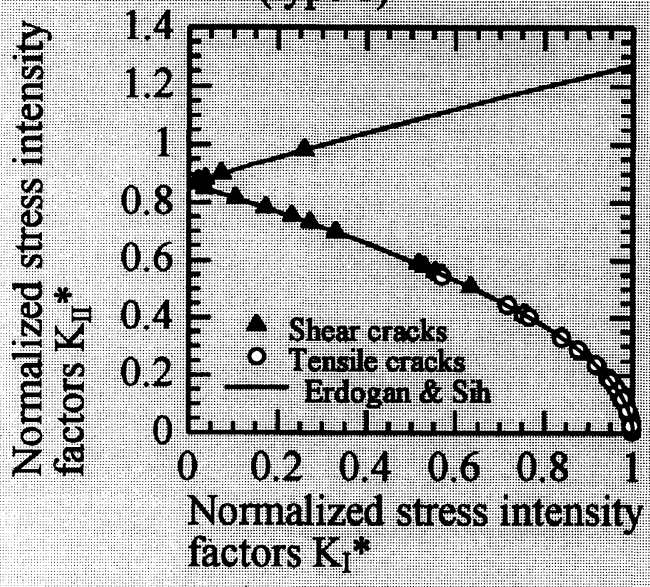

(b) Mortar specimen (type 1)

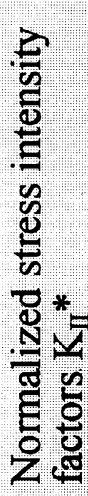

$\begin{array}{llllll}0 & 0.2 & 0.4 & 0.6 & 0.8 & 1\end{array}$ (c) Concrete specimen (type 2)
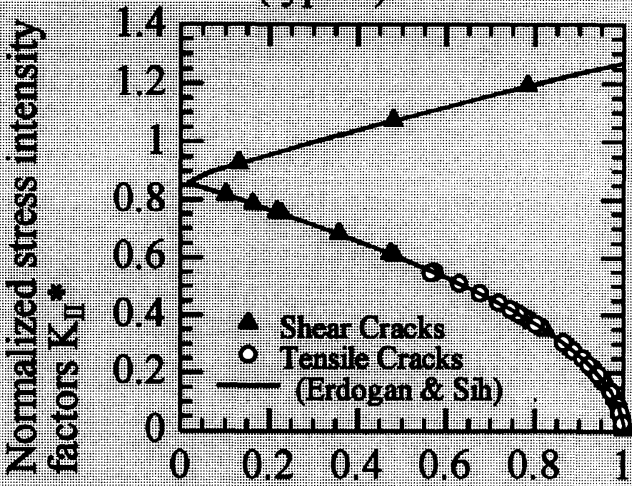

Normalized stress intensity factors $\mathrm{K}_{\mathbf{I}}^{*}$

(d) Mortar specimen (type 2)

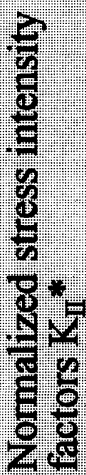
Normalized stress intensity factors $\mathrm{K}_{\mathrm{I}}^{*}$

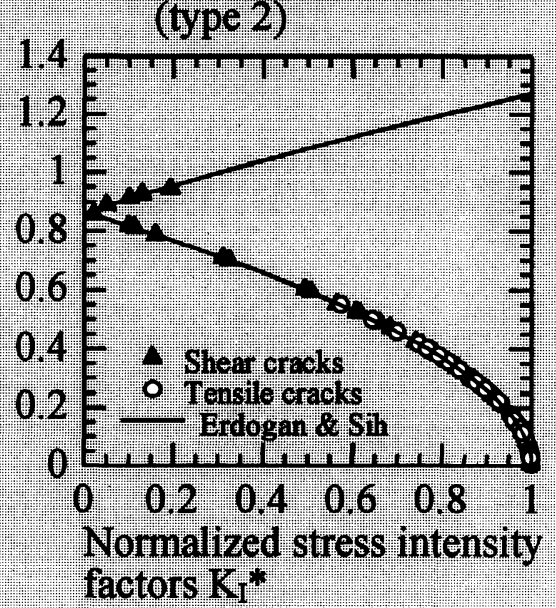

Fig. 7 Relation between nomal components, $K_{t}^{*}$ and shear components, $K_{t}^{*}$

\section{(3) Selection of feasible solution}

As all solutions from SiGMA were taking into consideration to the estimation, it was attempted to select feasible solution. A relationship between the mode I component $\mathrm{K}_{\mathrm{I}}^{*}=\mathrm{K}_{\mathrm{I}} / \mathrm{K}_{\mathrm{IC}}$ and the mode II component $\mathrm{K}_{\mathrm{II}}{ }^{*}=\mathrm{K}_{\mathrm{I}} / \mathrm{K}_{\mathrm{IC}}$ is plotted in the Fig. ${ }^{\cdot 7 \text {. The }}$ theoretical curve is obtained from Eqs.(5) and (6) by varying the angle $\theta$. It was realized that some (not presented here) of the normalized stress intensity factors were not coincident with the theoretical curve. This probably resulted from the misidentification of the vector $n^{*}$, because both vectors $\boldsymbol{l}$ and $\boldsymbol{n}^{*}$ were concurrently determined in the procedure.
From the figures, AE sources of which the normalized stress intensity factors $\mathrm{K}_{\mathrm{I}}^{*}$ are larger than 0.6 are mostly classified as tensile cracks, while those $\mathrm{K}_{\mathrm{II}}{ }^{*}$ larger than 0.6 are classified as shear cracks. Although Eqs.(3) and (4) are based on only the critical value $\mathrm{K}_{\mathrm{IC}}$, both types of cracks are identified. Crack extension is macroscopically governed by the mode I, whereas both types of mode I and mode II cracks are observed microscopically. 
(a) Concrete specimen (type 1)

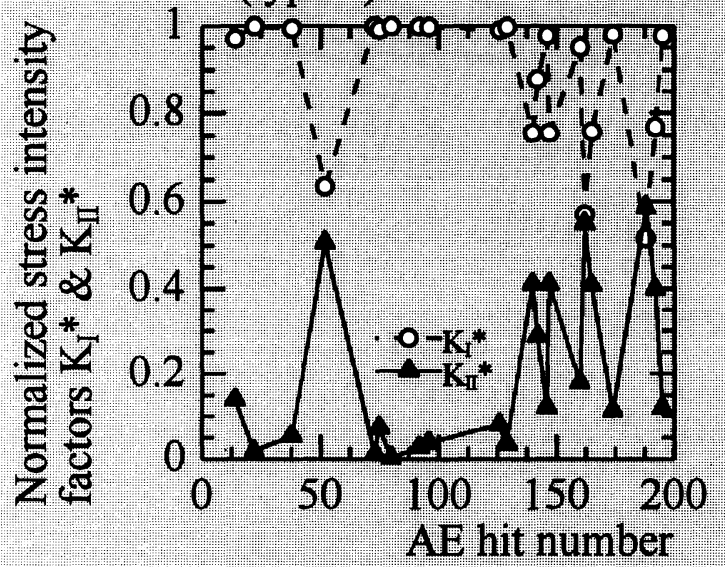

(c) Concrete specimen (type 2)
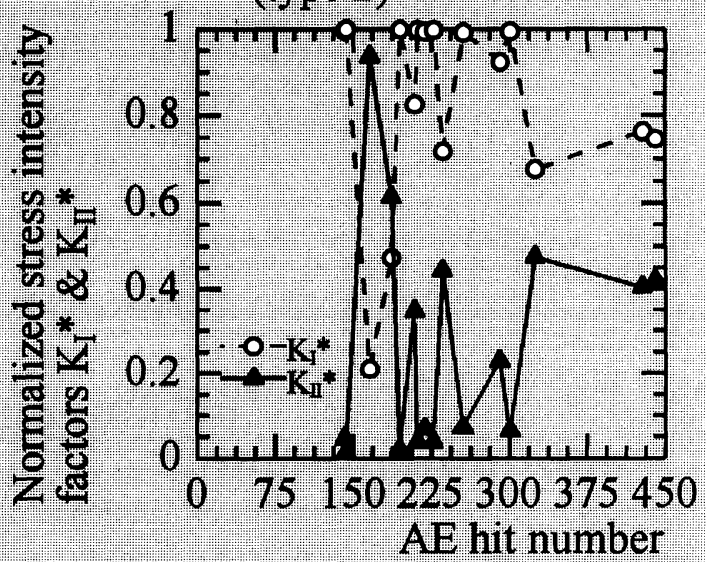

(b) Mortar specimen (type 1)

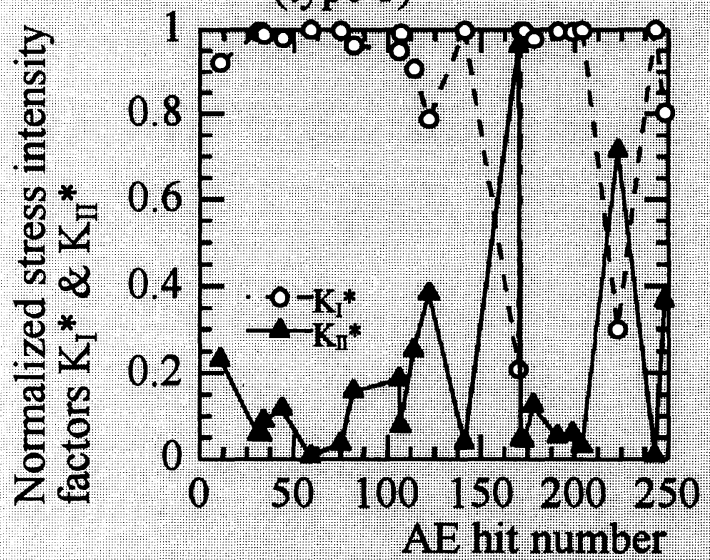

(d) Mortar specimen (type 2)
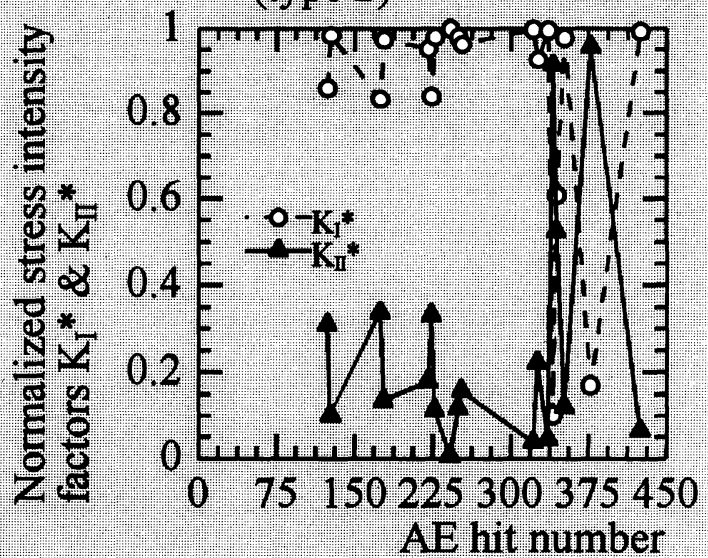

Fig. 8 Relation between nomalized stress intensity factors and cracks type in the fracture process zone

\section{(4) Cracking process}

Based on the normalized stress intensity factors plotted in Fig. 7, cracking process is studied. Normalized stress intensity factors, $\mathrm{K}_{\mathrm{I}}^{*}$ and $\mathrm{K}_{\mathrm{II}}{ }^{*}$ are plotted against $\mathrm{AE}$ hit number as shown in Fig. 8. In the case of the type 1 (Fig. $8(\mathbf{a})$ and (b)), normalized stress intensity factors $\mathrm{K}_{\mathrm{I}}^{*}$ is always dominated in the beginning stage of cracking. At the end stage of cracking process some micro-cracks of dominant normalized stress intensity factors, $\mathrm{K}_{\mathrm{II}}{ }^{*}$ are observed.
This implies that in the cracking process of macroscopically mode $I$, the mix-up of dominant $K_{I}^{*}$ and $K_{\mathrm{II}}^{*}$ modes is observed at the final stage. In contrast, the mix-up of the two modes is observed in the beginning stage in case of type 2 of concrete. In the case of type 2 of mortar, cracking process does not much differ from the case of type 1 of mortar. It can be said that the opening mode of micro-cracks is also dependent on the aggregate size or the homogeneity of the material. 


\section{CONCLUSION}

From the orientation of crack kinematics determined by the SiGMA procedure and the concept of the maximum circumferential stress, the normalized stress intensity factors, $\mathrm{K}_{\mathrm{I}}{ }^{*}=\mathrm{K}_{\mathrm{I}} / \mathrm{K}_{\mathrm{IC}}$ and $\mathrm{K}_{\mathrm{II}}{ }^{*}=\mathrm{K}_{\mathrm{II}} / \mathrm{K}_{\mathrm{IC}}$ are estimated. Conclusions are summarized as follows:

(1) Based on the crack direction determined from moment tensor components, a procedure to estimate normalized stress intensity factors is proposed.

(2) To study the contribution of shear motion at the crack surface, the relation between normalized stress intensity factors and the shear ratio $\mathrm{X}$ is investigated. From the results it is confirmed that the classification of the crack type based on the shear ratio in the SiGMA procedure is in reasonable agreement with the dominant mode of the stress intensity factors.

(3) In three-point bend tests of notched beams of type 1 (center notch) and type 2 (off-center notch), even crack propagation is governed by the critical stress intensity factor $\mathrm{K}_{\mathrm{IC}}$, a cluster of AE sources of mode I, mode II and mixed-mode are microscopically observed in the fracture process zone (FPZ).

(4) Cracking process is investigated based on the normalized stress intensity factors. It is concluded that the process of micro-cracking is also dependent on the size of aggregate and on the homogeneity of the material.

ACKNOWLEDGMENT: The authors wish to thank Messrs Ohtsuka and Yamamoto for their collaboration during the experiments and for the analysis.

\section{REFERENCES}

1) Hillerborg, A., Modeer, M., and Petersson, P-E.: Analysis of Crack Formation and Crack Growth in Concrete by means of Fracture Mechanics and Finite Elements, Cement and Concrete Research, Vol. 6, pp.773-782, 1976.

2) Cedolin, L., Dei Poli, S., and Iori, L.: Experimental Determination of the Fracture Process Zone in Concrete, Cement and Concrete Research, Vol. 13, pp. 557-567, 1983

3) Chahrour, A. H. and Ohtsu, M.: Crack growth prediction in scaled down model of concrete gravity dam, Theoretical \& Applied Fracture Mechanics, Vol. 21, 29-40, 1994.

4) Wadley, H. N. G. and Scruby, C. B.: Acoustic Emission Source Characterization, Advances in Acoustic Emission, Dunhart Publishers, Knoxville, pp. 125-153, 1981.

5) Ohtsu, M.: Source Mechanism and Waveform Analysis of Acoustic Emission in Concrete, J. of $A E, 2(1)$, pp. 103-112, 1982.

6) Ohtsu, M. and Ono, K.: A Generalized Theory of Acoustic Emission and Green's Functions in a Half Space, $J$ of $A E$, 3(1), pp. 27-40, 1984

7) Kim, K. Y. and Sachse, W.: Characterization of AE Signals from Indentation Cracks in Glass, Progress in Acoustic Emission II, JSNDI, pp. 163-172, 1984.

8) Yuyama, S., Okamoto, T., Shigeishi, M. and Ohtsu, M.: Acoustic Emission Generated in Corners of Reinforced Concrete Rigid Frame under Cyclic Loading, Materials Evaluation, Vol. 53 No. 3, pp. 409-412, 1995.

9) Erdogan, F. and Sih, G.C.: On the Crack Extension in Plates Under Plane Loading and Transverse Shear, J. of Basic Engineering, ASME, Vol. 85, pp. 519-527, 1963.

10) Ohtsu, M.: Acoustic Emission Theory for Moment Tensor Analysis, Research on Nondestructive Evaluation, Vol. 6, pp. 169-184, 1995.

11) Nomura, N., Mihashi, H. and Niiseki, S.: Influence of Coarse Aggregate Size on Fracture Energy and Tension Softening of Concrete, Concrete Research and Technology, Vol. 2, No.1, pp. 57-66, 1991.

(Received February 16,1998)

\section{AE-SiGMA 解析によるセメント系固化材料の破壊靭性に関する研究}

\section{Muzo C. MUNWAM. 大津 政康・重石 光弘}

SiGMA 解析によって AE 発生源のモーメントテンソルを求めれば, クラックの発生機構に関する定量的な 情報を得る事ができる．特にクラックの方向が決定しうる点に特徽がある．一方，線形破壊力学において は，最大周方向応力の方向に混合モードクラックが進展することが認められている. そこで, セメント系 固化材料のクラック進展実験において, SiGMA 解析で得られたクラックの進展方向から応力拡大係数を評価 することを試み, その值の変動から破壊課程を考察した. 